УДК 006:[621.774.3:669.14.018.8

Т. М. Буряк, Н. В. Ярошенко

Державне підприємство «Науково-дослідний та конструкторсько-технологічний інститут трубної промисловості ім. Я. Ю. Осади» (ДП «НДТІ»), м. Дніпропетровськ, Україна

\section{Зіставлення вимог} вітчизняних і міжнародних стандартів до труб з корозійностійкої сталі для ядерних енергетичних

\section{установок}

Проаналізовано стандарти і технічні умови (ГОСТ, ТУ, АSTM, EN) на труби з корозійностійкої сталі серії Х18Н10T (ТР321), що використовуються в конструкціях АЕС. Обгрунтовано доцільність оптимізації вимог до вітчизняних труб згідно з міжнародними стандартами та рекомендаціями стосовно наближення до євронорм.

Ключов і слов а: труба; корозійностійка сталь; стандарт; технічні вимоги; ядерна енергетика

\section{Т. Н. Буряк, Н. В. Ярошенко}

Сопоставление требований отечественных и международных стандартов к трубам из коррозионностойкой стали для ядерных энергетических установок

Проанализированы стандарты и технические условия (ГОСТ, ТУ, ASTM, EN) на трубы из коррозионностойкой стали серии Х18H10T (ТР321), которые используются в конструкциях АЭС. Обоснована целесообразность оптимизации требований к отечественным трубам в соответствии с международными стандартами и рекомендациями по приближению к евронормам.

Ключев ые слов а: труба; коррозионностойкая сталь; стандарт; технические требования; ядерная энергетика
$\Pi$ ісля підписання Україною Угоди про асоціацію 3 Евросоюзом особливої актуальності набуває розвиток енергетичної галузі та іiі інфраструктури, зокрема перехід на європейські норми. Оскільки майже $80 \%$ конструкційної основи АЕС становлять різноманітні трубні системи та трубопроводи, дуже важливим є забезпечення відповідної якості труб з корозійностійких сталей, вимоги до яких сформульовані у певних стандартах і технічних умовах. У раніше виконаних дослідженнях [1-4] проведено аналіз нормативних документів (НД) на труби для ядерних енергетичних установок та показано доцільність актуалізації й оптимізації вимог до них відповідно до сучасних досягнень науки і техніки, зокрема з урахуванням світової практики.

Мета цієї роботи - порівняльний аналіз нормативних вимог до труб, які діють в Україні (ГОСТ, ТУ) та за кордоном (EN, ASTM) для розроблення рекомендацій шодо їх наближення до міжнародних чи європейських норм і адаптації в ядерній енергетиці.

Об'єктом дослідження є такі НД:

- ГОСТ 9940-81 «Трубы бесшовные горячедеформированные из коррозионностойкой стали»;

- ГОСТ 9941-81 «Трубы бесшовные холодно- и теплодеформированные из коррозионностойкой стали»;

- ТУ 14-3-197:2006 «Труби безшовні з корозійностійких марок сталі з підвищеною якістю поверхні»;

- ASTM A213/A213 M-04b «Стандарт на бесшовные ферритные и аустенитные легированные котельные, пароперегревательные и теплообменные трубы»;

- ASTM A312/A312 M-01 «Стандартные технические условия для бесшовных и сварных труб (по размерному ряду) из аустенитных нержавеющих марок стали»;

- EN 10216-5:2004:Е «Бесшовные стальные трубы для эксплуатации под давлением. Технические условия поставки. - Часть 5: Трубы из нержавеющей стали»;

- EN 10217-7:2005:Е «Сварные стальные трубы для работы под давлением. Технические условия поставки. Часть 7: Трубы из нержавеющей стали»;

- ASTM A249/249 M-10а «Стандартная спецификация на сварные трубы из аустенитной нержавеющей стали для котлов, пароперегревателей, теплообменников и конденсаторов»;

- ГОСТ 11068-81 «Трубы электросварные из коррозионностойкой стали».

Матеріалом дослідження є труби з корозійностійкої сталі марок 08X18Н10T, 12X18Н10Т та їх закордонних аналогів ТР321, ТР321H, 1.4541.

Труби із зазначених корозійностійких марок сталі експлуатуються в обладнанні 2, 3, 4-го рівнів безпеки за класифікацією НП 306.2.141-2008 «Загальні вимоги безпеки атомних станщій». На вітчизняних АЕС згідно з чинними правилами і нормами використовуються безшовні труби, а за кордоном за певних умов та в разі відповідної якості допускаються труби зварні (наприклад, для конденсаторів). Труби за ТУ 14-3-197, ГОСТ 9940, ГОСТ 9941 входять до переліку матеріалів та напівфабрикатів, що допушені на АЕС відповідно до ПНАЭ Г 7-008-89 «Правила устройства и безопасной эксплуатации оборудования и трубопроводов атомных энергетических установок» (додаток 9); актуальність перегляду й оновлення даного документа показано в роботі [1].

Зіставимо технічні вимоги до труб для АЕС, наведені в різноманітних НД.

Вимоги до марки сталі. В ТУ 14-3-197:2006, які мають гриф «для АЕС», регламентовано вимоги до хімічного 
Зіставлення вимог вітчизняних і міжнародних стандартів до труб з корозійностійкої сталі для ядерних енергетичних установок

Таблиця 1. Нормовані вимоги до хімічного складу сталі марок 08Х18Н10Т (ТР321, 1.4541) та 12Х18Н10Т (ТР321Н)

\begin{tabular}{|c|c|c|c|c|c|c|c|c|c|c|}
\hline \multirow[b]{2}{*}{ нд } & \multirow[b]{2}{*}{ Марка сталі } & \multicolumn{9}{|c|}{ Масова частка, \%, хімічних елементів } \\
\hline & & C, $\max$ & $\underset{\max }{\mathrm{Si}}$ & $\begin{array}{l}\text { Mn, } \\
\max \end{array}$ & $\mathrm{Cr}$ & $\mathrm{Ni}$ & $\mathrm{Ti}$ & $\underset{\max }{\mathrm{S}}$ & $\underset{\max }{\mathbf{P}}$ & Інші \\
\hline ГОСТ 5632 & 08X18H10T & 0,08 & 0,8 & 2,0 & $17-19$ & $9-11$ & $5 \cdot \mathrm{C} \ldots 0,7$ & 0,020 & 0,035 & $\begin{array}{l}\text { Вимоги до залиш- } \\
\text { кових } \mathrm{Cu}, \mathrm{Mo}, \mathrm{V}, \mathrm{W}\end{array}$ \\
\hline ТУ $14-3-197$ & 08X18H10T & 0,08 & 0,8 & 1,5 & $17-19$ & $10-11$ & $5 \cdot$ C...0,6 & 0,020 & 0,035 & $\begin{array}{l}\mathrm{N}_{2}, \max 0,05, \text { iнше - } \\
\text { за ГОСТ } 5632\end{array}$ \\
\hline ASTM A 213 & TP321 & 0,08 & 1,0 & 2,0 & $17-19$ & $9-12$ & $5 \cdot(\mathrm{C}+\mathrm{N}) \quad \ldots 0,70$ & 0,030 & 0,045 & Не вказано \\
\hline ASTM A 312 & TP321 & 0,08 & 1,0 & 2,0 & $17-19$ & $9-12$ & $5 \cdot C \ldots 0,7$ & 0,030 & 0,045 & $\mathrm{~N}_{2}, \max 0,10$ \\
\hline ASTM A 249 & TP321 & 0,08 & 1,0 & 2,0 & $17-19$ & $9-12$ & $5 \cdot(\mathrm{C}+\mathrm{N}) \quad \ldots 0,70$ & 0,03 & 0,045 & $\mathrm{~N}_{2}, \max 0,10$ \\
\hline EN 10216-5 & 1.4541 & 0,08 & 1,0 & 2,0 & $17-19$ & $9-12$ & $5 \cdot$ C...0,7 & 0,015 & 0,045 & Не вказано \\
\hline EN 10217-7 & 1.4541 & 0,08 & 1,0 & 2,0 & $17-19$ & $9-12$ & $5 \cdot C \ldots 0,7$ & 0,015 & 0,045 & Не вказано \\
\hline ГОСТ 5632 & $12 \mathrm{X} 18 \mathrm{H} 10 \mathrm{~T}$ & 0,12 & 0,8 & 2,0 & $17-19$ & $9-11$ & $5 \cdot \mathrm{C} \ldots 0,8$ & 0,020 & 0,035 & $\begin{array}{l}\text { Вимоги до залиш- } \\
\text { кових } \mathrm{Cu}, \mathrm{Mo}, \mathrm{V}, \mathrm{W}\end{array}$ \\
\hline ASTM A 213 & TP321H & $0,04-0,10$ & 1,0 & 2,0 & $17-19$ & $9-12$ & $4 \cdot(\mathrm{C}+\mathrm{N}) \ldots 0,70$ & 0,030 & 0,045 & Не вказано \\
\hline ASTM A 312 & TP321H & $0,04-0,10$ & 1,0 & 2,0 & $17-19$ & $9-12$ & $4 \cdot \mathrm{C} \ldots 0,6$ & 0,030 & 0,045 & Не вказано \\
\hline ASTM A 249 & ТР321H & $0,04-0,10$ & 1,0 & 2,0 & $17-19$ & $9-12$ & $5 \cdot(\mathrm{C}+\mathrm{N}) \quad \ldots 0,70$ & 0,030 & 0,045 & Не вказано \\
\hline
\end{tabular}

складу сталі 08X18Н10Т. Безпосередньо в ГОСТ 994081, ГОСТ 9941-81, ГОСТ 11068-81 норми не наведено; є посилання на те, що хімічний склад матеріалу має задовольняти нормам ГОСТ 5632-72 «Стали высоколегированные и сплавы коррозионностойкие, жаростойкие и жаропрочные. Марки».

Кожен зі стандартів серії ASTM і EN на труби містить норми до хімічного складу. В стандартах серії ASTM визначено вимоги до основних (базових) елементів, а в ГОСТ, TУ та EN конкретизовано вимоги до залишкових домішок (табл. 1). Стандарти ASTM містять норми для сталі марок ТР321 та ТР321Н, які є аналогами відповідно марок 08X18H10T та 12X18H10T. У стандартах серії EN є марка 1.4541 , марок зі збільшеним вмістом вуглецю - аналогів 12Х18Н10Т чи ТР321Н - немає.

Норми повністю збігаються лише за вмістом вуглецю і хрому в сталях $08 \mathrm{X} 18 \mathrm{H} 10 \mathrm{~T}, \mathrm{TP} 321,1.4541$, а за іншими елементами, хоча й не суттєво, різняться.

Вимоги до термічної обробки і величини зерна. Термічна обробка дуже впливає на забезпечення якісних показників труб, насамперед на формування мікроструктури, корозійної тривкості, механічних властивостей тощо. Відповідно до ПНАЭ Г 7-008-89 призначена для АЕС металопродукція обов'язково має піддаватися термічній обробці. У більшості випадків це передбачено нормативними документами на труби, проте не всіма (табл. 2). Режими й вид термічної обробки суттєво не відрізняються. У вітчизняній практиці згідно з технологічним регламентом здійснюється відпал: нагрів до температур $1020 \ldots 1100{ }^{\circ} \mathrm{C}$, витримка, охолодження у воді чи повітрі (аустенізація). За кордоном - це так званий відпал на твердий розчин: нагрів і витримка при певній температурі, прискорене охолодження (у воді чи повітрі, температура вказана у стандартах: за ASTM - $1040 \ldots 1100{ }^{\circ} \mathrm{C}$, за EN $-1020 \ldots 1120{ }^{\circ} \mathrm{C}$ ). Задля поліпшення корозійної стійкості допускається коригування режиму термічної обробки чи проведення повторної (стабілізуючої).

Не для всіх видів труб висуваються вимоги до величини зерна. У вітчизняних ТУ не обмежується мінімальне зерно (не крупніше № 4 чи № 5), а в міжнародних стандартах або не нормується (EN), або не допускається дрібне зерно (за ASTM - № 7 чи крупніше).

Вимоги до механічних властивостей. Механічні властивості труб регламентуються на стан поставки за кімнатної температури і у важливих випадках - за підвищеної температури (табл. 3). Виняток становлять труби для найважливіших систем АЕС, властивості яких мають відповідати ТУ $14-3-197$, де границя плинності при $350{ }^{\circ} \mathrm{C}$ контролюється після аустенізації та в стані поставки, а за кімнатної температури - ні. Як видно з табл. 3, найдосконалішими за сукупністю вимог є норми за механічними властивостями у стандартах EN: ними обмежується верхнє значення границі міцності за кімнатної температури, за такою самою температурою нормовано границю плинності, показники якої при підвищеній температурі визначаються залежно від призначення труб в інтервалі $50 \ldots 550{ }^{\circ} \mathrm{C}$, $30-$ крема при $350{ }^{\circ} \mathrm{C}$.

Особливістю закордонних стандартів є те, що в них регламентуються деякі інші показники механічних властивостей в трубах на відміну від вітчизняних: твердість (ASTM), ударна в'язкість (EN), для зварних труб і деяких безшовних виконуються випробування на поперечний розрив кільцевого зразку (ASTM, EN).

Інші регламентовані критерії якості. В усіх НД як обов'язковий або додатковий критерій нормується стійкість до міжкристалітної корозії (МКК). Стандартами ASTM додатково передбачено випробування на пітингову корозію й корозійне розтріскування під напругою, на стійкість до МКК зварних швів за методикою, принципово відмінною від вітчизняних методик [5] 
Т. М. Буряк, Н. В. Ярошенко

Таблиия 2. Вимоги до термічної обробки труб і норми по величині зерна

\begin{tabular}{|c|c|c|c|c|}
\hline НД & Марка сталі & Вид обробки & Обов'язковість термічної обробки & Величина зерна \\
\hline ТУ 14-3-197 & $08 \mathrm{X} 18 \mathrm{H} 10 \mathrm{~T}$ & Ааустенізація & Так & $\begin{array}{l}\text { Не крупніше за № } 5 \text { для труб } \\
\text { діаметром до } 76 \text { мм вкл., } \\
\text { не крупніше за № } 4 \text { для труб } \\
\text { діаметром понад } 76 \text { мм }\end{array}$ \\
\hline ГОСТ 9940 & $\begin{array}{l}08 \mathrm{X} 18 \mathrm{H} 10 \mathrm{~T} \\
12 \mathrm{X} 18 \mathrm{H} 10 \mathrm{~T}\end{array}$ & Не вказано & За вимогою споживача & Не вказано \\
\hline ГОСТ 9941 & $\begin{array}{l}08 \mathrm{X} 18 \mathrm{H} 10 \mathrm{~T} \\
12 \mathrm{X} 18 \mathrm{H} 10 \mathrm{~T}\end{array}$ & Не вказано & $\begin{array}{l}\text { Так, але на вимогу споживача допускається } \\
\text { без термічної обробки }\end{array}$ & Не вказано \\
\hline ГОСТ 11068 & 08X18H10T & Не вказано & Так & Не вказано \\
\hline \multirow{2}{*}{ ASTM A 312} & TP321 & \multirow{2}{*}{$\begin{array}{l}\text { Відпал на твер- } \\
\text { дий розчин }\end{array}$} & \multirow{2}{*}{ Так } & Не вказано \\
\hline & TP321H & & & № 7 чи крупніше (№ 6, 5, ...) \\
\hline \multirow{2}{*}{ ASTM A 213} & TP321 & \multirow{2}{*}{$\begin{array}{l}\text { Відпал на твер- } \\
\text { дий розчин }\end{array}$} & \multirow{2}{*}{ Так } & Не вказано \\
\hline & TP321H & & & № 7 чи крупніше \\
\hline \multirow{2}{*}{ ASTM A 249} & TP 321 & \multirow{2}{*}{$\begin{array}{l}\text { Відпал на твер- } \\
\text { дий розчин }\end{array}$} & \multirow{2}{*}{ Так } & Не вказано \\
\hline & TP321H & & & № 7 чи крупніше \\
\hline $\begin{array}{l}\text { EN 10216-5, } \\
\text { EN 10217-7 }\end{array}$ & 1.4541 & $\begin{array}{l}\text { Відпал на твер- } \\
\text { дий розчин }\end{array}$ & Так & Не вказано \\
\hline
\end{tabular}

Таблиця 3. Вимоги до механічних властивостей* труб

\begin{tabular}{|c|c|c|c|c|c|c|c|c|}
\hline \multirow{2}{*}{ НД } & \multirow{2}{*}{ Марка сталі } & \multicolumn{5}{|c|}{ У стані поставки при $20^{\circ} \mathrm{C}$} & \multirow{2}{*}{$\begin{array}{c}\begin{array}{c}\text { У стані поставки } \\
\text { при } 350{ }^{\circ} \mathrm{C}\end{array} \\
\sigma_{0,2}, \text { МПа }\end{array}$} & \multirow{2}{*}{ Примітка } \\
\hline & & $\sigma_{\mathbf{B},}$, МПа & $\sigma_{0,2}$, МПа & $\sigma_{1,0}$, МПа & $\delta_{5}, \%$ & $\delta_{50}, \%$ & & \\
\hline ТУ-14-3-197 & 08X18H10T & $\min 549$ & Не вказано & Не вказано & $\min 37$ & Не вказано & $\begin{array}{l}\text { 196-344 для труб діа- } \\
\text { метром до } 76 \text { мм вкл.; } \\
\text { 186-333 для труб діа- } \\
\text { метром понад } 76 \text { мм }\end{array}$ & $\begin{array}{l}\text { Норми по } \sigma_{0,2} \\
\text { при } 350{ }^{\circ} \mathrm{C}-\text { піс- } \\
\text { ля аустенізації }\end{array}$ \\
\hline ГОСТ9940 & \multirow{2}{*}{ 08X18H10T } & $\min 510$ & Не вказано & Не вказано & $\min 40$ & Не вказано & \multirow{2}{*}{$\begin{array}{l}\text { За згодою зі спожива- } \\
\text { чем }\end{array}$} & \\
\hline ГОСТ9941 & & $\min 549$ & Не вказано & Не вказано & $\min 37$ & Не вказано & & \\
\hline ASTM A213 & $\begin{array}{l}\text { ТР321, } \\
\text { ТP321H }\end{array}$ & $\min 515$ & Не вказано & $\min 205$ & Не вказано & $\min 35$ & Не вказано & \\
\hline ASTM A312 & $\begin{array}{l}\text { TP321, } \\
\text { TP321H }\end{array}$ & $\min 515$ & Не вказано & $\min 205$ & Не вказано & Не вказано & Не вказано & \\
\hline ASTM A249 & $\begin{array}{l}\text { ТР321, } \\
\text { TP321H }\end{array}$ & $\min 515$ & Не вказано & $\min 205$ & Не вказано & $\min 35$ & Не вказано & \\
\hline EN 10216-5 & 1.4541 & $460-680$ & $\min 180$ & $\min 215$ & $\min 35$ & $\min 30$ & $\begin{array}{l}\text { min } 130 \text { - для холодно- } \\
\text { деформованих труб; } \\
\text { min } 94-\text { для гаряче- } \\
\text { деформованих труб }\end{array}$ & $\begin{array}{l}\text { Норми по } \sigma_{0,2}, \sigma_{1,0} \\
\text { в інтервалі } 50- \\
550{ }^{\circ} \mathrm{C}\end{array}$ \\
\hline EN 10217-7 & 1.4541 & $500-730$ & $\min 200$ & $\min 235$ & $\min 35$ & $\min 30$ & $\min 130$ & $\begin{array}{l}\text { Норми по } \sigma_{0,2}, \sigma_{1,0} \\
\text { в інтервалі } 50- \\
550{ }^{\circ} \mathrm{C}\end{array}$ \\
\hline ГОСТ11068 & 08X18H10T & $\min 530$ & $\min 216$ & Не вказано & $\min 37$ & Не вказано & Не вказано & \\
\hline ГОСТ 9940 & \multirow{2}{*}{$12 \mathrm{X} 18 \mathrm{H} 10 \mathrm{~T}$} & $\min 529$ & $\min 216$ & Не вказано & $\min 40$ & Не вказано & \multirow{2}{*}{$\begin{array}{l}\text { За згодою зі спожива- } \\
\text { чем }\end{array}$} & \\
\hline ГОСТ 9941 & & $\min 549$ & $\min 216$ & Не вказано & $\min 35$ & Не вказано & & \\
\hline
\end{tabular}

Примітка. $\sigma_{\text {в }}$ - границя міцності чи тимчасовий опір розриву; $\sigma_{0,2}, \sigma_{0,1}-$ границя плинності; $\delta_{5}, \delta_{50}-$ відносне видовження. 
3 усього масиву розглянутих у даному дослідженні НД, норми забрудненості неметалевими включеннями - стрічковими нітридами та карбонітридами титану - наведено лише в ТУ-14-3-197. Даний показник якості є досить відповідальним за експлуатаційну надійність труб в умовах корозійних і механічних навантажень. У зарубіжних стандартах контроль нітридів і карбонітридів не передбачено.

Технологічні випробування на сплющування та роздачу передбачено в усіх розглянутих стандартах.

Випробування на статичний згин відрізків труб (патрубків чи сегментів від них) на певний кут $\left(90 \ldots 180^{\circ}\right)$ в даних стандартах (крім ГОСТ 11068) не передбачено.

Для контролю якості зварного з'єднання по зарубіжних стандартах, на відміну від вітчизняних, виконується випробування на згин з оборотним перегином (ASTM) та на утому знакозмінним згином (EN) зразків труб зі швом.

Випробування на поперечний розрив, розширення чи розвальцювання кільцевого зразку від труби передбачені лише в стандартах ASTM і EN, зокрема як для зварних труб, так і безшовних, залежно від додаткових умов.

Випробування на бортування вимагаються лише ГОСТ 11068 для зварних труб.

У вітчизняних НД значну роль у контролі якості поверхні відведено візуальному огляду, в зарубіжних стандартах - фізичним методам.

Випробування гідравлічним тиском передбачено в усіх стандартах. У вітчизняних нормативах здатність труб витримувати гідравлічний тиск забезпечується технологією виробництва і гарантується виробником (крім ГОСТ 11068). Оскільки після такого випробування постає низка проблем (просушування внутрішнього каналу труб, можливе погіршення властивостей за рахунок наклепу внаслідок дії випробувального тиску), допускається заміна випробувань гідравлічним тиском на неруйнівний контроль - ультразвуковий (УЗК) чи вихорострумовий (BCK). УЗК передбачено вітчизняними НД (обов'язково за ТУ і за вимогою споживача ГОСТами), а ВСК - ні. Згідно з АSTM, ультразвуковий чи вихрострумовий контроль виконують за додатковими вимогами на вибір, а згідно з ЕN обов'язковими є обидва види. Зазначимо, що норми та умови виконання неруйнівного контролю в європейських і міжнародних стандартах значно жорсткіші, ніж у вітчизняних. Для зварних труб імпортного виробництва стандартами передбачено радіографічний контроль якості зварних швів, за ГОСТ 11068 ця вимога відсутня.

Оскільки міжнародними стандартами висувається цілий комплекс високих вимог до труб з корозійностійкої сталі та контролю їх якості, вітчизняними виробниками освоєно виготовлення й поставка за межі України труб за стандартами ISO, EN, ASTM, для цього напрацьовано досвід і є сучасна технічна база. Але для законодавчо врегульованої можливості використання на АЕС України труб за європейськими чи міжнародними вимогами потрібно актуалізувати правила і норми в ядерній енергетиці, насамперед це стосується Додатку 9 ПНАЭ Г 7-008-89.

\section{Висновки}

І̇з порівняльного аналізу технічних вимог до труб 3 корозійностійкої сталі 08...12Х18Н10Т (ТР321, ТР321Н, 1.4541), що регламентуються вітчизняними ТУ, ГОСТами та міжнародними стандартами серії ASTM і EN, випливає:
1. Повної аналогії між розглянутими документами не існує. Вимоги і норми, що висуваються до труб, близькі між собою, але повністю не збігаються. Відмінність спостерігається залежно від призначення труб, способу виготовлення (зварні, безшовні, холодно- чи гарячедеформовані), методів контролю та у підходах різних технічних комітетів зі стандартизації до вибудови вимог і критерієв якості.

2. Серед проаналізованих нормативних документів найжорсткіші вимоги в стандартах EN - як на безшовні, так і на зварні труби. Жорсткі вимоги до безшовних труб установлені ТУ 14-3-197. Досить високі вимоги до якісних показників у ASTM A 249 (зварні труби) та ASTM A 213 (зварні й безшовні труби).

3. Враховуючи, що на відміну від ГОСТ 11068, стандартами ASTM A 249, ASTM A 213 і EN 10217-7 висувається цілий комплекс підвишених вимог до зварних труб, можна розглядати питання їх використання на AEC у системах, які не впливають на безпеку, наприклад у конденсаторах і певному теплообмінному обладнанні, що відповідає сучасним світовим тенденціям.

4. До цього часу в Україні база гармонізованих з міжнародними національних стандартів створювалась їх актуалізацією ідентичного чи модифікованого ступеню. Оскільки переходові на міжнародні та європейські стандарти має передувати внесення відповідних змін до законодавства, правил і норм у сфері ядерної енергетики, доцільним є поетапне наближення до норм ЄС. Можливі такі варіанти:

a) першочергово прискорений перехід на гармонізовані з EN стандарти модифікованого ступеню;

б) для труб відповідального призначення - перехід на стандарти EN (наприклад, замість ТУ-14-3-197 впровадити EN 10216-5), а для труб загального призначення перехід на стандарти ASTM (замість ГОСТ 9940 та ГОСТ 9941 впровадити ASTM А 213 чи ASTM А 312);

в) поступовий повний перехід до норм СС з внесенням національних поправок за потреби, зокрема перегляд чи адаптація методик з контролю якості продукції.

\section{Список використаної літератури}

1. Вахрушева В. С. Аналіз нормативної документації на труби, елементи і деталі трубопроводів для атомно-енергетичного комплексу України / В. С. Вахрушева, Т. М. Буряк, Н. В. Ярошенко // Ядерна та радіаційна безпека. - 2012. - № 2(54). - С. 42-44.

2. Анализ технической документации на трубы из коррозионностойкой стали специального назначения / В. П. Сокуренко, Е. Я. Лезинская, Л. Г. Ковалева, Т. Н. Буряк // Информ. обзор сер.: Трубное производство. - М. : Ин-т «Черметинформация», 1992. - Вып. 1. $-15 \mathrm{c}$.

3. Вахрушева В. С. О целесообразности корректировки требований к трубам из аустенитных коррозионностойких сталей для ядерных энергетических установок / В. С. Вахрушева, Т. Н. Буряк, Н. В. Ярошенко // Материалы 19 Междунар. конф. по физике радиационных повреждений и радиашионному материаловедению, Алушта, Крым, 2010. Харьков : ННЦ «ХФТИ», 2010. - С. 147

4. Лезинская Е. Я. Проблемы оценки качества металла труб активной зоны атомных реакторов в процессе дореакторных испытаний / Е. Я. Лезинская, Т. Н. Буряк // Вопросы атомной науки и техники. - 2004. № 3(85). - C. $66-74$.

5. Вахрушева В. С., Ярошенко Н. В., Малиш О. Д. Сучасні методи контролю механічних та металографічних властивостей у національних стандартах на металопродукцію / В. С. Вахрушева, Н. В. Ярошенко, О. Д. Малиш // Науково-технічний вісник УкрНДНЦ. - 2007. Вип. 5. - С. 51-54. 


\section{References}

1. Vakhrusheva V. S., Buryak T. N., Yaroshenko N. V. (2012), Analysis of Regulatory Documents on Pipes, Components and Details of Piping for Nuclear Power Complex of Ukraine [Analiz normatyvnoi dokumentatsii na truby, elementy i detail truboprovodiv dlia atomnoenerhetychnoho kompleksu Ukrainy. Yaderna ta radiatsiina bezpeka], Nuclear and Radiation Safety, No. 2(54), pp. 42-44. (Ukr)

2. Sokurenko V. P., Lezinskaia E. Ya., Kovaleva L. G., Buryak T. N. (1992), Analysis of Technical Documents on Stainless Steel Pipes of a Special Purpose [Analiz tekhnicheskoi dokumentatsii na truby iz korrozionnostoikoi stali spetsialnogo naznacheniia], Inform. video cer.: Pipe Production, Moscow, Chermetinformaitsiia, Vol. 1, p. 15. (Rus)

3. Vakhrusheva V. S., Buryak T. N., Yaroshenko N. V. (2010), On Expediency to Improve Requirements for Austenitic Stainless Steel Pipes of Nuclear Power Installations [O thelesoobraznosti korrektirovki trebovanii $\mathrm{k}$ trubam iz austenitnykh korrozionnostoikikh stalei dlia yadernykh energeticheskikh ustanovok], Materials of the 19th International Conference on Physics of Radiation Damages and Radiation Materials Science, Alushta, Crimea, Kharkiv, NSC "KIPT", p. 147. (Rus).
4. Lezinskaia E. Ya., Buryak T. N. (2004), Challenges in Quality Assessment of Core Pipe Metal during Pre-Reactor Tests [Problemy otsenki kachestva metalla trub aktivnoi zony atomnykh reaktorov $\mathrm{v}$ protsesse doreaktornykh ispytanii. Voprosy atomnoi nauki i tekhniki], Problems of Nuclear Science and Technology, No. 3(85), pp. 66-74. (Rus).

5. Vakhrusheva V. S., Yaroshenko N. V, Malysh O. D. (2007), State-of-the-art Methods to Check Mechanical and Metallographic Properties in National Standards on Metal Products [Suchasni metody kontroliu mekhanichnykh ta metalohrafichnykh vlastyvostei $\mathrm{u}$ natsionalnykh standartakh na metaloproduktsiiu], Scientific and Technical Bulletin, SE "UkrRTCSSQP”, Vol. 5, pp. 51-54. (Ukr).

\section{Правила для авторів}

1. Рукопис статті журналу подається у вигляді твердої копії з підписами всіх авторів на останній сторінці, а також електронної версії (на електронному носії або електронною поштою). До публікації приймаються лише оригінальні твори, присвячені проблемам ядерної та радіаційної безпеки.

2. Стаття має містити УДК. Українською, російською та англійською мовами наводяться анотація, назва статті, ключові слова, прізвище, ім'я та по батькові автора, назва організації, де працює автор.

3. Загальний обсяг статті разом з графічними матеріалами не повинен перевищувати 18 сторінок формату А4. На одній сторінці може бути не більш як 30 рядків та до 60 знаків (з урахуванням розділових знаків і проміжків між словами) у кожному рядку. Розмір шрифту підготовленого на комп'ютері матеріалу 14; міжрядковий інтервал - 1,5. Розміри полів, мм: зліва -30 , справа -10 , зверху -20 , знизу -25 .

4. Текст набирається шрифтом Times New Roman у редактоpi Microsoft Word. Графічний матеріал (чорно-білий) подається у форматі EPS, TIFF або JPG-файлів з густиною точок на дюйм 300-600 dpi. Їлюстрації подаються окремо від тексту.

5. Статті, які є результатами робіт, проведених в організаціях, повинні мати супровідний документ від цих організацій.

6. Разом зі статтею до редакції журналу має бути поданий документ про можливість відкритої публікації матеріалів, а також про згоду на поширення їх через мережу Їнтернет.

7. До авторського оригіналу статті на окремому аркуші додаються: прізвище, ім'я, по батькові (повністю) автора, організація, в якій він працює, посада, вчений ступінь, звання, мобільний, службовий і домашній номери телефону, службова та домашня адреси.

8. Скорочення слів, словосполучень, назв, термінів, за винятком загальноприйнятих, можливе тільки після їх повного першого згадування в тексті.
9. Зміст наукових статей будується за такою структурою:

коротка анотація - стислі відомості про статтю (до 10 рядків);

встуn - постановка наукової проблеми, її актуальність, зв'язок з державними науковими та практичними програмами, значення вирішення проблеми;

основні дослідження $i$ публікації - аналітичний огляд останніх досліджень і пу блікацій з даної проблеми, виокремлення не розв'язаних раніше питань;

формування мети статmі - опис головної ідеї даної публікації, чим вона відрізняється, доповнює та поглиблює вже відомі підходи, які нові факти, закономірності висвітлює (до 15 рядків);

викладення основного змісту проведеного дослідження - головна частина статті, де висвітлюються основні положення дослідження, програма і методика експерименту, отримані результати та їх обгрунтування, виявлені закономірності, аналіз результатів, особистий внесок автора;

висновки - основні підсумки, рекомендації, значення для теорії й практики, перспективи подальших досліджень;

список літератури - перелік літературних джерел, на які $€$ посилання в тексті статті; вказати автора та назву твору, місце публікації (для книжки - місто та видавництво, для статті - назву збірника чи журналу, його номер або випуск), дату публікації, кількість сторінок у книжці або сторінки, на яких вміщено статтю.

10. Матеріали, які неохайно оформлені і не відповідають зазначеним вимогам, редакцією не розглядаються.

11. Для скорочення витрат на видання журналу виплата авторського гонорару не передбачається.

12. Матеріали, що надійшли до редакції, авторам не повертаються 